\title{
Calculation of Overall Equipment Effectiveness (OEE) in Rotary Machine 5 Feet in Order to Total Productive Maintenance Implementation
}

\author{
Sigit Dwi Cahyono ${ }^{1}$, Fourry Handoko ${ }^{2}$, Nelly Budiharti ${ }^{3}$ \\ 1,2,3 Student, Post-graduate Department of Industrial Engineering, ITN Malang
}

\begin{abstract}
PT. Tri Tunggal Laksana is an industry that focusing on wood processing. During the production period, the tools have a high frequency of trouble. Total Productive Maintenance (TPM) has been recognized as one of the significant operation strategy to regain the production losses due to equipment inefficiency. Many organizations have implemented TPM to improve their equipment efficiency and to obtain the competitive advantage in the global market in terms of cost and quality. In the implementation of TPM in a manufacturing organization, both Human-oriented and Process-oriented strategy has been identified as critical success factors. Based on the problem background, the research do because Rotary Machine 5 Feet having so many trouble in July to December of 2019 during the production period. After the research is done, the average of OEE calculation is equal to $56.29 \%$. It can be concluded that the effectiveness of the machine is still far from world class standard that is equal to $85 \%$. Six big losses factors that contribute most to Rotary Machine effectiveness is Reduce Speed Losses that is $22,31 \%$. According to the fishbone diagram analysis factors that causing the OEE is low can be identified so that improvement can be done immediately.
\end{abstract}

Keywords:- Fishbone Diagram, Overall Equipment Effectiveness, Six Big Losses, Total Productive Maintenance.

\section{INTRODUCTION}

In this competitive world, total elimination of waste is necessary for the survival of the organization. The wastes generated due to the failure shutdown of facilities that have been built, with huge investment and also waste such as defective products should be absolutely eliminated. The main goal of each industry is to obtain maximum profits by optimal utilization of resources. The problem faced by the company today is how to carry out the production process effectively and efficiently by utilizing existing resources both raw materials, production machinery and human resources. In fact, PT. Tri Tunggal Laksana as one of wood processing industry face a problem in Rotary machine having breakdown about 244.8 hours during July to December 2019.

TPM is one of a Lean Manufacturing (LM) tools focus on optimizing machine and process productivity and an important pillar in the continuous improvement process [1]. TPM is an innovative maintenance approach to eliminate failures/breakdowns, optimize equipment effectiveness, and promote autonomous maintenance by operators of daily activities involving all employees [2]. TPM is a maintenance and production program that is designed primarily to maximize the effectiveness of all tools through the participation, engagement and motivation of all staff / employees. The six major equipment losses, to zero, have been recognized as necessary for corporate survival. This approach emphasizes the role of teamwork, small group activities, and the participation of all employees to accomplish equipment improvement objectives. It challenges a sense of joint responsibility between operators and maintenance workers, not only to keep the machines running smoothly, but also to extend and optimize their overall performance. It is also defined as, bringing both functions (production and maintenance) togetherby a combination of good working practices, team working, and continuous improvement. TPM is intended to bring both functions (production and maintenance) together by a combination of good working practices, team working and continuous improvement. Based on the problems above, this study aims to: (1) assess the effectiveness of Rotary Machine 5 Feet using OEE. (2) defines the six big losses that occur in Rotary machine effectiveness. (3) Analyze cause and effect of the losses using fishbone diagram.

\section{LITERATURES STUDY}

Many companies try to improve their business performance through the application of TPM methods. Total productive maintenance (TPM) is an original idea from Nakajima (1988) that emphasizes the utilization and involvement of human resources and preventive maintenance systems to maximize the effectiveness of equipment by involving all departments and organizational functions [3].TPM is an innovative approach to maintenance that optimizes equipment effectiveness, eliminates breakdowns, and promotes autonomous maintenance by operators from day to day activities involving total employee. TPM is a maintenance and production program designed mainly to maximize the effectiveness of all tools through participation and motivation of all staff/employee and the basic practices of TPM are often called the "pillars" or "elements" of TPM

Overall Equipment Effectiveness (OEE) is a measurement used to determine how efficiently a machine is running. OEE is a hierarchy of metrics that focuses on how effectively a manufacturing operation is utilized [4]. 
The losses are divided into six major categories, which affect the overall performance of the equipment namely:

Equipment failures/breakdown losses are the time losses and quantity losses caused by defective products.

Set-up and adjustment losses are defined as time losses resulting from downtime and defective products that occur when production of one item ends and the equipment is adjusted to meet the requirements of another item.

$>$ Idling and minor stop losses occur when the production is interrupted by a temporary malfunction or when a machine is idling.

$>$ Reduced speed losses refer to the difference between equipment design speed and actual operating speed.

$>$ Reduced yield losses occur during the early stages of production from machine start up to stabilization.

$>$ Quality defects and reworks are losses in quality caused by malfunctioning of production equipment.
The first two losses are known as down time loss and are used to calculate availability of a machine. The third and fourth are speed losses that determine the performance efficiency and the final two losses are considered to be losses due to defects in the products. OEE is measured in terms of these six losses, which are function of availability rate, performance rate and quality rate of the machine, production line or factory [3].

OEE is an abbreviation for the manufacturing metric Overall Equipment Effectiveness. OEE takes into account the various sub components of the manufacturing process Availability, Performance and Quality. After the various factors are taken into account the result is expressed as a percentage. This percentage can be viewed as a snapshot of the current production efficiency for a machine, line or cell. The process of OEE analysis is figure out in figure 1 below:

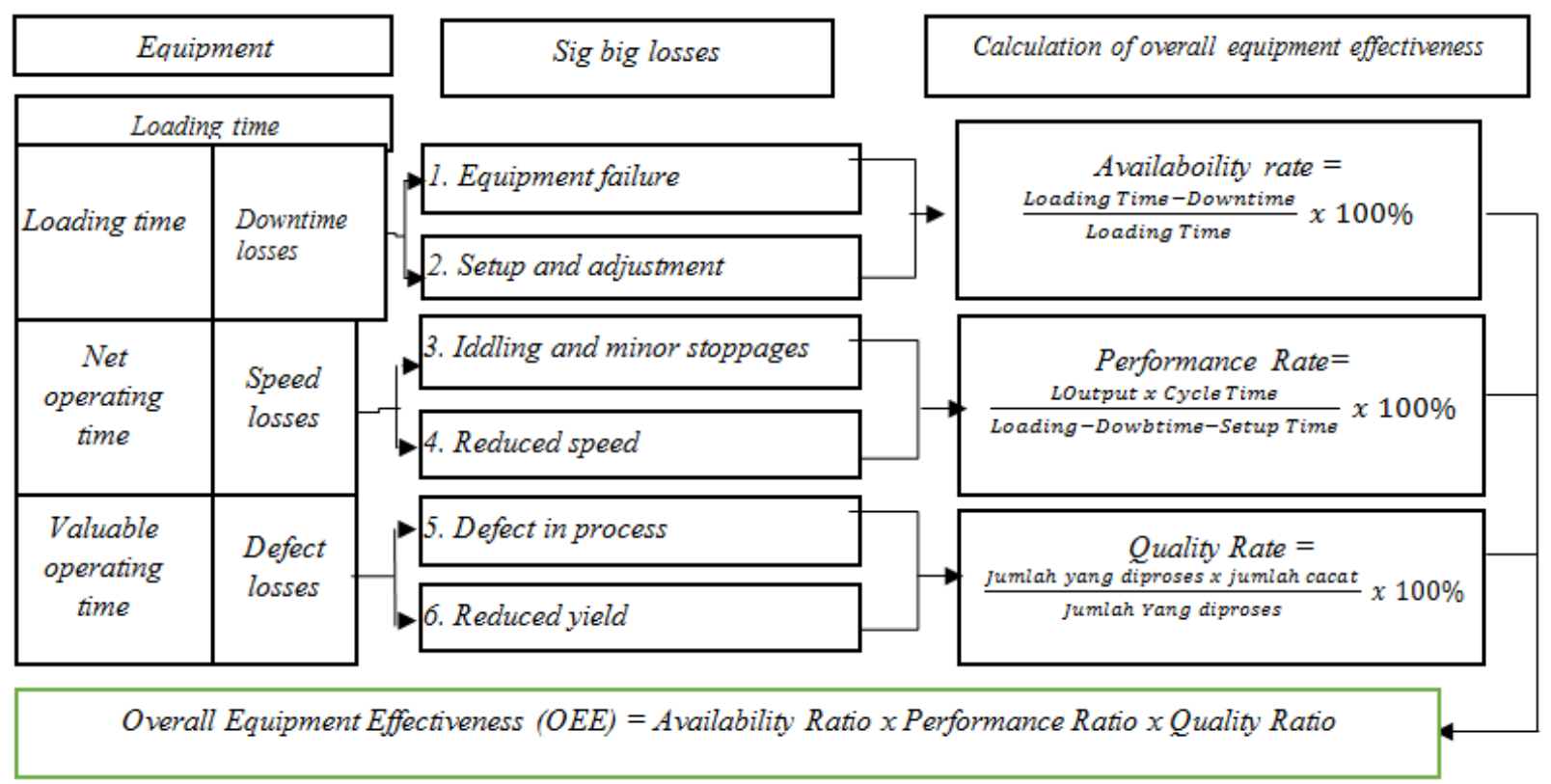

Fig 1:- Overall Equipment Effectiveness Process

Source: Nakajima (1988)

\section{RESULT AND DISCUSSION}

These are the production data of PT. Tri Tunggal Laksana on July to December 2019:

\begin{tabular}{|c|c|c|c|}
\hline No. & Month & Raw Material $\left(\mathrm{m}^{3}\right)$ & $\begin{array}{c}\text { Veneer } \\
\left(\mathrm{m}^{3}\right)\end{array}$ \\
\hline 1 & July & 1024.73 & 332.30 \\
\hline 2 & August & 1114.61 & 218.25 \\
\hline 3 & September & 1544.82 & 439.52 \\
\hline 4 & October & 1814.03 & 677.96 \\
\hline 5 & November & 2201.71 & 226.525 \\
\hline 6 & December & 2518.65 & 144.974 \\
\hline
\end{tabular}

Table 1:- Production Data from July to December 2019 


\section{Measuring Availability Rate}

The availability is a percentage of time a machine is available to produce parts. The formula for this calculation is:

Availability Ratio $=\frac{\text { Loading Time }- \text { Downtime }}{\text { Loading Time }} \times 100 \%$

\begin{tabular}{|c|c|c|c|c|}
\hline No. & Month & $\begin{array}{c}\text { Loading Time } \\
\text { (hour) }\end{array}$ & $\begin{array}{c}\text { Downtime } \\
\text { (hour) }\end{array}$ & $\begin{array}{c}\text { Availability Ratio } \\
(\boldsymbol{\%})\end{array}$ \\
\hline $\mathbf{1}$ & July & 357.75 & 92.3 & 74.20 \\
\hline $\mathbf{2}$ & August & 344.50 & 62.8 & 81.77 \\
\hline $\mathbf{3}$ & September & 331.25 & 85.4 & 74.22 \\
\hline $\mathbf{4}$ & October & 304.75 & 55.6 & 81.76 \\
\hline $\mathbf{5}$ & November & 331.25 & 35.4 & 89.31 \\
\hline $\mathbf{6}$ & December & 318.00 & 50.8 & 84.03 \\
\hline \multicolumn{2}{|c|}{ Average } \\
\hline
\end{tabular}

Table 2:- Availability Rate Data of Rotary Machine

\section{Measuring Performance Rate}

The performance metric is a pure measurement of speed that is designed to exclude the effect of quality and availability. The formula for calculating performance rate is:

Performance Ratio $=\frac{\text { Output } x \text { Ideal Cycle Time }}{\text { Operating Time }} \times 100 \%$

\begin{tabular}{|c|c|c|c|c|c|}
\hline No. & Month & $\begin{array}{c}\text { Output } \\
\left(\mathbf{m}^{\mathbf{3}}\right)\end{array}$ & $\begin{array}{c}\text { Ideal Cycle Time } \\
(\mathbf{h o u r})\end{array}$ & $\begin{array}{c}\text { Operating Time } \\
\left(\mathbf{h o u r} / \mathbf{m}^{\mathbf{3}}\right)\end{array}$ & $\begin{array}{c}\text { Performance Ratio } \\
(\boldsymbol{\%})\end{array}$ \\
\hline $\mathbf{1}$ & July & 645.08 & 0.24 & 247.45 & 62.57 \\
\hline $\mathbf{2}$ & August & 766.92 & 0.25 & 264.37 & 72.52 \\
\hline $\mathbf{3}$ & September & 1033.56 & 0.16 & 229.18 & 72.16 \\
\hline $\mathbf{4}$ & October & 1195.24 & 0.14 & 233.82 & 71.57 \\
\hline $\mathbf{5}$ & November & 1500.19 & 0.14 & 279.18 & 75.23 \\
\hline $\mathbf{6}$ & December & 1563.08 & 0.11 & 251.20 & 68.45 \\
\hline & \multicolumn{2}{|c|}{ Average } \\
\hline
\end{tabular}

Table 3:- Performance Rate Data of Rotary Machine

\section{Measuring Quality Rate}

The quality metric is a pure measurement of process yield that is designed to exclude the effect of availability and performance. The formula for calculating quality is:

Quality Ratio $=\frac{\text { output }- \text { Rejuced Yield }- \text { Reject }}{\text { Output }} \times 100 \%$

\begin{tabular}{|c|c|c|c|c|c|}
\hline No. & Month & $\begin{array}{c}\text { Output } \\
\left(\mathbf{m}^{\mathbf{3}}\right)\end{array}$ & $\begin{array}{c}\text { Reduced Yield } \\
\left(\mathbf{m}^{\mathbf{3}}\right)\end{array}$ & $\begin{array}{c}\text { Reject } \\
\left(\mathbf{m}^{\mathbf{3}}\right)\end{array}$ & $\begin{array}{c}\text { Quality Ratio } \\
(\mathbf{\%})\end{array}$ \\
\hline $\mathbf{1}$ & July & 1000.85 & 8.20 & 0 & 98.73 \\
\hline $\mathbf{2}$ & August & 1021.02 & 2.56 & 0 & 99.67 \\
\hline $\mathbf{3}$ & September & 1432.12 & 6.71 & 0 & 99.35 \\
\hline $\mathbf{4}$ & October & 1666.45 & 3.45 & 0 & 99.71 \\
\hline $\mathbf{5}$ & November & 1935.18 & 26.80 & 0 & 98.21 \\
\hline $\mathbf{6}$ & December & 2302.77 & 40.85 & 0 & 97.39 \\
\hline
\end{tabular}

Table 4:- Quality Rate Data of Rotary Machine 


\section{Measuring Overall Equipment Effectiveness}

$\mathrm{OEE}=$ Availability $\times$ Performance $\mathrm{x}$ Quality

\begin{tabular}{|c|c|c|c|c|c|}
\hline No. & Month & $\begin{array}{c}\text { Availability Ratio } \\
(\boldsymbol{\%})\end{array}$ & $\begin{array}{c}\text { Performance Ratio } \\
(\boldsymbol{\%})\end{array}$ & $\begin{array}{c}\text { Quality Ratio } \\
(\boldsymbol{\%})\end{array}$ & $\begin{array}{c}\text { OEE } \\
(\boldsymbol{\%})\end{array}$ \\
\hline $\mathbf{1}$ & July & 74.20 & 62.57 & 98.73 \\
\hline $\mathbf{2}$ & August & 81.77 & 72.52 & 95.84 \\
\hline $\mathbf{3}$ & September & 74.22 & 72.16 & 99.35 \\
\hline $\mathbf{4}$ & October & 81.76 & 71.57 & 99.71 \\
\hline $\mathbf{5}$ & November & 89.31 & 75.23 & 98.21 \\
\hline $\mathbf{6}$ & December & 84.03 & 68.45 & 57.21 \\
\hline & Average & 80.88 & 70.41 & 58.35 \\
\hline
\end{tabular}

Table 5:- OEE Data of Rotary Machine

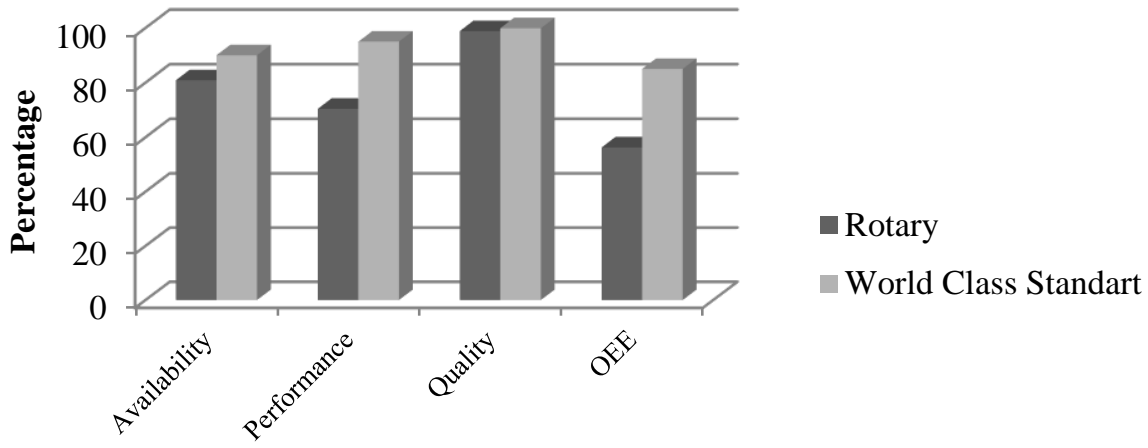

Variable

Fig 2:- Comparison Ratio Diagram of Rotary Machine

Figure 2 shows the comparison between actual OEE ratio and the world class standard ratio in which availability and performance rate are below the world standard. OEE value of Rotary machine is $56.29 \%$ under $85 \%$. It explains that Rotary machine has low efficiency when it compare of global standards ratio. The factors of the losses should be identify further so the improvement can be identified.

\section{Identifying Six Big Losses}

\begin{tabular}{|c|c|c|}
\hline No. & Six Big Losses & Average Rate (\%) \\
\hline $\mathbf{1}$ & Breakdown Losses & 12.20 \\
\hline $\mathbf{2}$ & Setup and Adjustment Losses & 2.92 \\
\hline $\mathbf{3}$ & Idling and Minor Stoppages & 22.31 \\
\hline $\mathbf{4}$ & Reduce Speed Losses & 0.63 \\
\hline $\mathbf{5}$ & Reduce Yield / Scrap Losses & 0 \\
\hline $\mathbf{6}$ & Defect in Process and Rework & \\
\hline
\end{tabular}

Table 6:- Six Big Losses in Rotary Machine

\section{Fishbone Diagram}

Reduce speed losses is the major factor that cause the Rotary machine having low OEE (56.29\%). This losses occur due to defect when the machine or equipment is operating at lower than recommended speed. The reason for the lower speed is that operators are not sure of the quality level produced under normal speeds. To improve these losses, we use fishbone diagram or Ishikawa diagram. The fishbone diagram identifies many possible causes for an effect or problem. It can be used to structure a brainstorming session. It immediately sorts ideas into useful categories. 


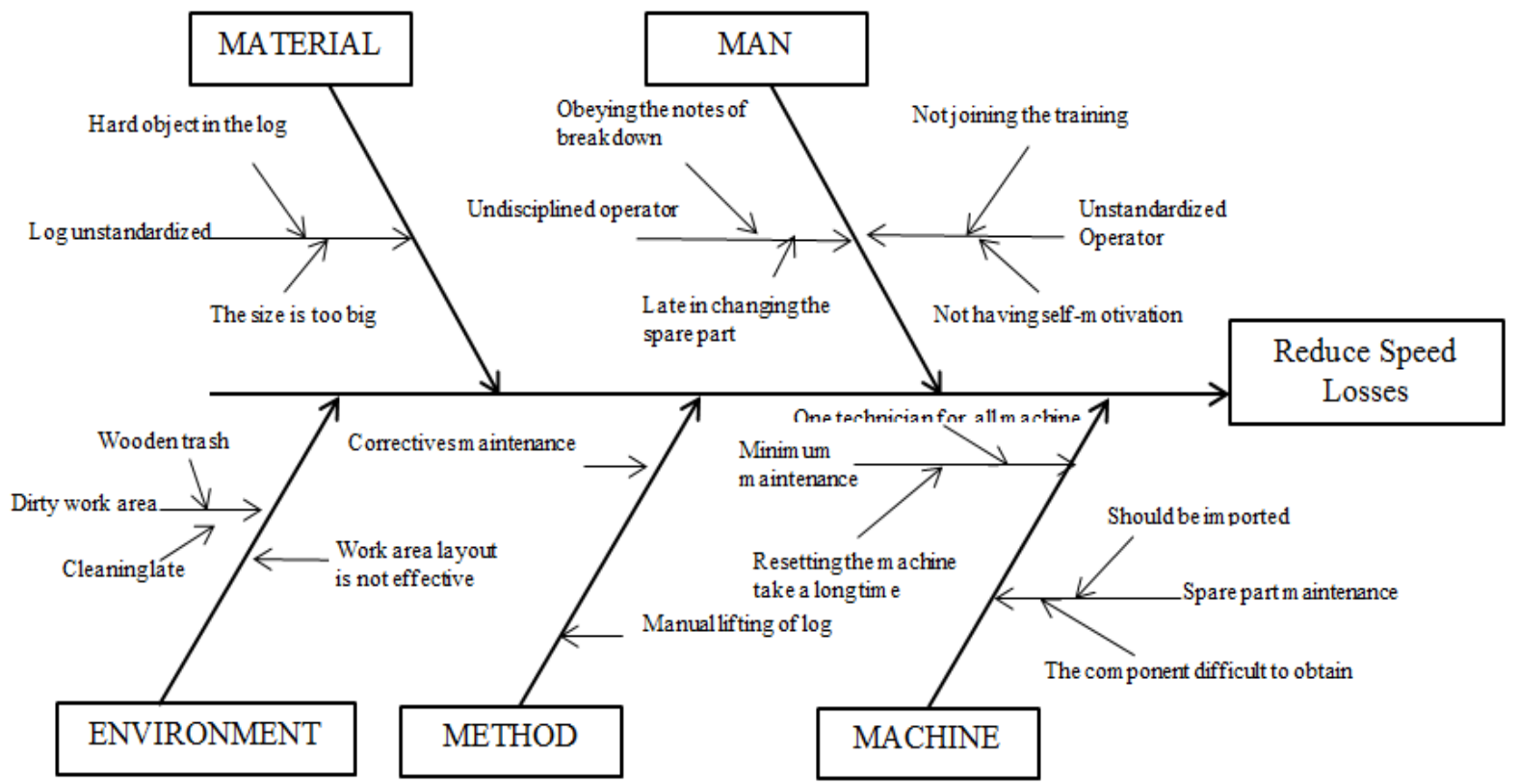

Fig 3:- Ishikawa Diagram of Reduce Speed Losses in Rotary Machine

From figure 3 we can identify the problems that causes reduce speed losses in Rotary machine. It can be identified based on 5 factors:

\section{> Material}

Material factor or raw material due to log wood which is not in accordance with the standard, namely the presence of foreign objects in the $\log$, the log size is too large (exceeding the machine's capacity). Improvements that need to be done are to meet the standard size of the wooden log and conduct an initial inspection using a metal detector to detect the presence of foreign objects in the log.

\section{$>$ Man}

- The operator is undisciplined to do component replacement and does not keep track of damage properly. Improvements that need to be done are implementing operator discipline by providing a reward and punishment system.

- Workers or operators do not meet human resource qualification standards because they do not attend training and do not have a strong motivation to learn. For that the company needs to require operators to attend training and improve their skills.

\section{Environment}

- The work area is dirty because the amount of wood waste that is scattered and not immediately cleaned can disturb the mobility of workers and interfere with the work activities of the machine, for example the machine stops moving due to the presence of squashed wood waste. To overcome this problem, workers should applying the habits and discipline of workers to keep the work area clean and neat.

- The log yard location is far from the main machine, causing workers need more time to distribute raw materials to the production machine.
$>$ Method

- Machine maintenance methods need to be repaired so as to prevent further damage. Self-maintenance by operator can provide improvements in engine maintenance methods.

- Transportation of raw materials that have so far been carried out manually can be used as tools such as forklifts to speed up and facilitate the distribution of raw materials.

\section{Machine}

- The engine maintenance system is not optimal because there is only one technician, so it takes more time for the repair process.

- Machine components are damaged and the original components are not yet available. For that the company can provide components in advance through imported components so that the authenticity of the goods can be guaranteed to ensure the machine runs according to its capacity.

\section{CONCLUSION}

Overall Equipment Effectiveness (OEE) is a common measure of performance to indicate the utilization of the machine. Following conclusion is derived from the analysis of OEE in Rotary machine 5 feet:

$>$ The OEE value of Rotary machine 5 Feet is $56.29 \%$ in average of July to December 2019.

$>$ Reduce Speed Losses is the factor that affect the most. It is $22.31 \%$ of the losses.

To improve the Total Productive Maintenance in the company, it is important to apply the fishbone diagram analysis result 


\section{REFERENCES}

[1]. Y. Mishra and M. Aarif. 2016. "Total Productive Maintenance," Emerg. Trends Eng. Manag. Sustain. Dev

[2]. P. S. Ahuja and J. S. Khamba. 2008 "Total Productive Maintenance: Literature Review and Directions," Int. J. Qual. Reliab. Manag., vol. 25, no. 7, pp. 709-756,

[3]. S. Nakajima. 1988. Introduction to Total Productive Maintenance, Productivity press, Cambridge, MA

[4]. D.H Stamatis, 2010. The OEE Primer: Understanding overall Equipment Effectiveness, Reliability, and Maintainability. Productivity Press, New York. 